
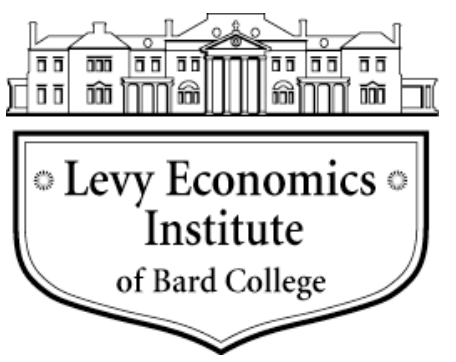

Working Paper No. 700

\title{
Is There Room for Bulls, Bears, and States in the Circuit?*
}

by

\author{
L. Randall Wray \\ Levy Economics Institute of Bard College
}

December 2011

*For "Contemporary Capitalism: Its Financial Circuits, Its Transformation and Future Prospects," May 31-June 1, 2011; Ottawa, Ontario, Canada.

The Levy Economics Institute Working Paper Collection presents research in progress by Levy Institute scholars and conference participants. The purpose of the series is to disseminate ideas to and elicit comments from academics and professionals.

Levy Economics Institute of Bard College, founded in 1986, is a nonprofit, nonpartisan, independently funded research organization devoted to public service. Through scholarship and economic research it generates viable, effective public policy responses to important economic problems that profoundly affect the quality of life in the United States and abroad.

Levy Economics Institute

P.O. Box 5000

Annandale-on-Hudson, NY 12504-5000

http://www.levyinstitute.org 


\begin{abstract}
This paper takes off from Jan Kregel's paper “Shylock and Hamlet, or Are There Bulls and Bears in the Circuit?” (1986), which aimed to remedy shortcomings in most expositions of the “circuit approach.” While some “circuitistes” have rejected John Maynard Keynes’s liquidity preference theory, Kregel argued that such rejection leaves the relation between money and capital asset prices, and thus investment theory, hanging. This paper extends Kregel's analysis to an examination of the role that banks play in the circuit, and argues that banks should be modeled as active rather than passive players. This also requires an extension of the circuit theory of money, along the lines of the credit and state money approaches of modern Chartalists who follow A. Mitchell Innes. Further, we need to take Charles Goodhart's argument about default seriously: agents in the circuit are heterogeneous credit risks. The paper concludes with links to the work of French circuitist Alain Parguez.
\end{abstract}

Keywords: Circuit Approach; Liquidity Preference; Banks as Ephor of Capitalism; J. M. Keynes; J. A. Schumpeter; A. Parguez; J. A. Kregel; Chartalist; Modern Money Theory; State Money; Credit Money; Default

JEL Classifications: B2 B24 B25 B31 B51 B52 E11 E12 E41 E43 E51

*For “Contemporary Capitalism: Its Financial Circuits, Its Transformation and Future Prospects,” May 31-June 1, 2011; Ottawa, CA. 


\section{INTRODUCTION}

The title of this piece is a play on the title of Jan Kregel's paper "Shylock and Hamlet, or Are There Bulls and Bears In the Circuit?” (1986), which is appropriate as I am drafting this in Copenhagen only a few kilometers from "Elsinor" castle. Of additional relevance is that we have just finished a conference at which Alain Parguez gave a masterful presentation of the problems with the set-up of the European Union—a topic to which I will turn near the end of this chapter.

I will not replicate in detail the arguments made in Kregel's article. Briefly, his complaint was that the circuit approach is confined to Keynes' industrial circulation and gives short shrift to the financial circulation. Somewhat ironically, I had moved to Bologna in 1986a year after his publication - to write my dissertation on the relation between the two spheres of circulation, attempting a synthesis between a Circuitiste/Neo-Ricardian view of the industrial sphere and a Minskian approach to the financial sphere. Needless to say, that did not go over well—and so I moved on to endogenous money as a less controversial topic (Wray 1990). In any event, Kregel's contribution had already made the essential points. In the TOM (Treatise on Money), Keynes had the state of bearishness together with the behavior of banks determine the price of capital goods (Keynes 1976 [1930]). In the GT (General Theory), bearishness was replaced with liquidity preference (Keynes 1964 [1936]). Unfortunately, the "monetary details" fell into the background, as Keynes presented a general theory of asset price determination, with liquidity preference playing the driving role. As Kregel put it:

It is thus the 'bearishness' or 'liquidity preference' theory of the value of capital assets that I referred to as the missing Prince of Denmark in the post-Keynesian Hamlet. The circuit approach, while it claims to reflect Keynes' conception of a monetary production economy seems to deny the importance of the link between monetary factors and the prices of capital goods, between the rate of interest and investment; it appears to mistake Shylock for Hamlet (Kregel 1986, p. 16).

Again, I do not want to rehash the details, but the problem identified by Kregel was an inconsistency in the usual Post Keynesian presumption that capital goods prices are determined as some exogenous markup over wages. Further, independence of the level of real profit and interest rates was assumed, and would require that interest rates do not affect the rate of investment. Yet, following Keynes, "When Hamlet plays the Prince, it is impossible to postulate a change in the rate of interest without a change in liquidity preference which will change the prices of capital assets and thus the investment decisions of entrepreneurs” (Ibid., p. 21). With 
respect to the two spheres of circulation, this is important because when financial assets offer better returns, finance flows away from the industrial circulation. "The financial circulation expands at the expense of the industrial circulation. Hamlet walks the ramparts, 'to invest or not to invest' that is a question that depends on liquidity preferences of entrepreneurs” (Ibid.). Yet, "it is a question that is difficult to address if it is presumed that investment is independent of all but the willingness of Shylock to create sufficient credit to allow his clients to pay his exorbitant rates of interest” (Ibid.).

To put it as simply as possible, Keynes used liquidity preference theory to determine the demand prices for all assets that can be held through time, including capital assets. The composition of returns, q-c+l, vary by asset type with demand prices adjusting to equalize expected returns to holding them. From this, we get the marginal efficiencies, including the marginal efficiency of money (MEM) which acts as the "rooster" setting the standard that all other assets must beat. Changes to liquidity preference affect that standard and hence demand prices. To be newly produced, the demand price of capital assets must exceed supply prices. It is here that, as a rough rule of thumb, we can take the PK markup approach. Since capital assets come out of the sphere of production, they must have a supply price-a "cost price" to cover production costs plus normal profit. A rise of liquidity preference that raises interest rates hence counts twice-once in raising the MEM and again in raising production costs (since interest is a cost that must be included in supply price). Following Minsky (1975), we can draw an investment "demand curve" (Pk) that is horizontal up to the point that exhausts internal funds; beyond that point it slopes down due to borrower's risk. The "supply curve” (Ps) is also horizontal to the same point, then slopes up due to lender's risk (that includes the stated interest charged on borrowed funds). An increase of liquidity preference also counts twice here: increasing borrower's and lender's risk so that both curves shift inward. In fact, even the horizontal portion of the demand curve shifts down—so we could say that liquidity preference counts three times.

A rise of liquidity preference thus increases the MEM and lowers the Pk while raising the Ps. This results in less investment, which lowers profits (all else equal) through the Kalecki profits equation. In Keynes, the equalization of expected returns is at the point in time that decisions are made. There are short-term expectations-which govern decisions made regarding use of existing capacity_and long-term expectations which concern the decision to invest. Since capital assets are both part of current output (using existing capacity to produce them) and 
as well are assets that are expected to generate returns in the future, the two different price systems come together in the investment decision (again, Pk must exceed Ps, the former coming out of the asset price system and the latter coming out of the current output price system).

As Kregel argued in another famous paper, Keynes adopted three different methodological approaches in the GT (Kregel 1976). In the first, he assumed that expectations are always fulfilled; in the second, they can be disappointed but do not change expectations; and in the third, disappointments lead to changes of expectations. While Minsky's FIH (financial instability hypothesis) would appear to mostly use the last method (optimistic expectations are disappointed, leading to "fire sales" of assets and a Fisher debt deflation), he also noted the importance of self-fulfilling expectations in both boom and bust-generating a euphoric boom or self-reinforcing crash.

For these reasons, it would be a mistake to leave bulls and bears out of the circuit. I have never known what to think of claims by some circuitistes that liquidity preference ought to be left out of the analysis — or worse yet, claims that both liquidity preference theory and Minsky’s FIH amount to loanable funds theory. Any PK theory of investment must leave room for expectations — what else would drive decisions made about purchasing capital goods that will last years or even decades? - and out in the real world there are always alternative assets that do not require a commitment that is so difficult to unwind should expectations prove to have been unwise. Further, it is very hard to believe that lenders do not also have expectations about prospective earnings of borrowers, also realizing that failure is possible. Hence it makes sense to build in margins of safety — which will be reduced when optimism grows - as well as higher lending rates to cover greater lender's risk. Banks should not be treated as passive lendershorizontally supplying loans and deposits on demand, and with firms doing their duty to borrow funds, pay wages, and produce output with no regard for the future since profits are mechanically generated and assured by Kalecki!

\section{CAN “ANYONE” CREATE MONEY? JUST HOW SPECIAL ARE BANKS?}

The purpose of my contribution is not to review or to critique previous work in this area. Rather, what I will do is to explicate a simple extension to Kregel's paper by linking liquidity preference (or bearishness) to Minsky’s claim that “anyone” can create money with the paradoxical realization that default is possible. When we add to the mix bears, default, states 
(state money and lender of last resort), and the universal law of credit, we get much closer to a comprehensive approach to money. While the circuit approach deserves credit for focusing on the role played by the banker and money creation as a pre-condition to allowing production decisions to go forward, ignoring the role played by expectations, uncertainty, and default is akin to performing Hamlet without the Prince.

In what follows, I presume all readers are familiar with the simple circuits and the most common extensions - which were developed largely following the pioneering work of Alain Parguez and Graziani (1990).

\section{MONEY AS CREDIT-DEBT RELATION}

I find the circuit approach particularly useful for driving home the point that the finance for spending must come from somewhere. Most recognize that to finance a purchase one needs to use income, to sell an asset, or to borrow. At the individual level, that is certainly true. Yet, the "finance" that comes from income flows as well as the receipts from sales of assets also must come from somewhere-and an "infinite regress" is not logically compelling. The typical neoclassical deus ex machina source of finance is saving-but if saving is in financial form it must have been generated by someone else's spending, another infinite regress. Hence, when the circuitiste begins with a bank loan to finance purchase of commodities (to be used to produce commodities) all logical problems are resolved.

Spending and creation of "money" in the form of a bank deposit are linked. It is best to think of these as balance sheet entries: the bank accepts the IOU of the borrower and credits her demand deposit; the borrower's IOU is offset by the credit to her deposit. Spending then simply shifts the demand deposit to a seller. Money is created "endogenously" to finance spending. Later, when loans are repaid, the demand deposit as well as the borrower's IOU are debitedmoney is destroyed. There is no magic involved, no "manna from heaven", no separation of the “real” (say, IS curve) from the "monetary” (LM curve). As Clower would remark, money buys goods and goods buy money but goods do not buy goods. Barter is ruled out, as one must first

obtain money_from income flows, asset sales, or borrowing — before spending. And the money must get created with an initiating purchase.

Of course, all the money gets destroyed only if it is all spent in a manner that allows all debtors to retire debt. There can be slips between lips and cups. Two main problems arise: 
money might get into the wrong hands, and it might not get spent (these are linked). In the typical presentation, workers might decide to save some of their wages, meaning that capitalists cannot retire loans taken out to pay the wage bill. Bonds can be sold either to workers or to banks to allow retirement of the short term loans. Less often considered is the possibility that workers do spend all wages but expenditures are not distributed properly among firms to allow loan repayment. Again, disappointed firms could sell bonds to firms with windfall sales. That unhappy result would not be sustainable for long — and indeed might not even be plausible for the shortest run-who wants to buy the debt of a firm that cannot realize revenues through sales?

The possibility for a realization crisis is inherent in the chaos of decentralized decision making. (There must be heterogeneous agents in the circuit!) And if the debtor defaults on her loan, the bank's balance sheet takes a loss. In the simplest expositions of the circuit, the bank would be toast (like Citibank today!) — it does not have loan loss reserves or equity to withstand the hit. If we ignore real world accounting rules, a circuitiste bank can always make the deposits “good” since they are mere liabilities — even if all of a bank’s assets drop to zero value, it can always provide its own IOUs to its creditors (depositors). But that cannot happen in the real world.

First, there are regulatory or generally accepted accounting rules (RAP or GAAP; or even CRAP: creative regulatory accounting principles!), but we will ignore those for now. Second, there is a widely recognized pseudo-logical rule that one cannot retire one's own debt by issuing another debt. In the simple circuit, a bank receives its own IOU (deposit) when the borrower retires her IOU (loan). But if the borrower defaults, the bank will have IOUs outstanding in excess of its assets. Even if all the other assets prove to be good, so that borrowers use bank deposits to retire them, there will remain bank liabilities outstanding that cannot be retired by repaying loans. In the anarchic unplanned economy, the bank with excess outstanding liabilities has no assets to deliver to clear its accounts when deposits are shifted (as would occur if the bank's depositor makes a payment to someone with a deposit in another bank). While other banks could simply clear deposits by extending credit to the insolvent bank, this, too, is implausible for the simple reason that the bank does not have adequate good assets to serve as collateral. This problem can be finessed if there is only one bank-a not entirely satisfactory solution. (We need heterogeneous banks, too!) 
Out in the real world, banks clear accounts using a third party liability - the reserves provided by the central bank. The central bank can lend reserves to the bank facing a clearing drain — enabling it to clear accounts even where it is insolvent. While a real world central bank would act as lender of last resort to allow the deposits to clear, it should quickly move to resolve the insolvent bank. Otherwise, it will be throwing "good money" after "bad" —and although its claims on the insolvent bank will match its own new liabilities it cannot count on sufficient "reflux" as the reserves accumulate in the balances of solvent banks due to adverse clearing against the insolvent bank. Like the insolvent bank, the central bank’s money IOUs would not be destroyed at the end of any circuit that included insolvent banks.

\section{DEFAULT AND MONEY}

We have, of course, just introduced default risk into the circuit. Goodhart (2008) argues that the reason that conventional economics cannot find a role for money or for financial institutions in its rigorous ("general equilibrium”) models is because default is ruled out by assumption. All IOUs are presumed to be equally safe because all promises are always kept as all debts are always paid. (This is the so-called “transversality condition.” Indeed, many such models employ a representative agent who is both debtor and creditor and who quite rationally would never schizophrenically default on herself. Heterogeneous borrowers are necessary!) This means that all can borrow at the risk-free interest rate and that any seller would accept a buyer's IOU; there is no need for cash and never any liquidity constraint. Nor would we need any specialists such as banks to assess credit-worthiness, nor deposit insurance, nor a central bank to act as lender of last resort.

Obviously, almost all interesting questions about money, financial institutions, and monetary policy are left to the side if we ignore liquidity and default risk. There would be no need for a monetary circuit and thus no circuitiste approach. The simple circuitiste circuit is a logical impossibility. We must have heterogeneity of banks and borrowers, we must have default risk, we must have expectations (bulls and bears), and we must have a central bank.

Let us turn to the most fundamental question about debt: just what is owed when an IOU is issued? All IOUs share one common requirement: the issuer must accept back her own IOU when it is presented (Innes 1913; Wray 2004). In the circuit, the bank takes back its own IOU (demand deposit) when a debtor presents it to pay off a loan. Another promise that many 
monetary IOUs carry is convertibility on demand (or on some specified condition such as a waiting period) to another monetary IOU or even to a commodity. For example, on a gold standard, the government might promise to convert its currency (an IOU stamped on coin or paper) to so many ounces of precious metal. Or, a country on a fixed exchange rate might promise to convert its currency to so many units of a foreign currency. Banks promise to convert their demand deposit IOUs to domestic high powered money (currency or reserves at the central bank).

It is important to remember that a promise to convert is not fundamental to the issue of an IOU - it is in a sense voluntary. Indeed, in the simple expositions of the circuit, with one bank and no central bank, there is no promise to convert at all. With multiple banks, each can promise to convert to the liabilities of others at par. We know that at least in the case of the US, before 1913 and the creation of the Fed, bank liabilities did not clear at par. Par clearing is ensured by central bank willingness to act as lender of last resort; it is further strengthened by government-provided deposit insurance. The first is a mostly short-term assurance that deposits clear at par, while the second ensures deposit holders against insolvency of a bank.

We have just introduced a central bank and government deposit insurance. We need to examine the role played by the state in the monetary system. These can make banks "special” by reducing or entirely eliminating default risk by banks on their own liabilities.

\section{INTRODUCING THE STATE}

Modern "fiat” currencies on floating exchange rates are accepted with no promise to convert. Many attribute this to legal tender laws, where sovereign governments have enacted legislation requiring their currencies to be accepted in payments. On the other hand, the Euro paper currency makes no promises and has no legal tender laws requiring its use. Further, throughout history there are many examples of governments that passed legal tender laws, but still could not create a demand for their currencies. (See Wray 1998, Goodhart 1998, and Knapp 1973 [1924].) Hence, there are currencies that readily circulate without any legal tender laws (such as the Euro) as well as currencies that were shunned even with legal tender laws.

If currency cannot be exchanged for precious metal in many countries, and if legal tender laws are neither necessary nor sufficient to ensure acceptance of a currency, and if the government's “promise to pay” really amounts to nothing (except exchanging its currency for its 
currency), then why would anyone accept a government's currency? As followers of the "taxes drive money" approach have emphasized, it is because the sovereign government has the authority to levy and collect taxes (and other payments made to government including fees and fines). Tax obligations are levied in the national money of account—-dollars in the US, Canada, and Australia.

Further, the sovereign government also determines what can be delivered to satisfy the tax obligation. In all modern nations, it is the government's own currency (technically, high powered money that includes coins, notes, and central bank reserves-for convenience I will call these "currency") that is accepted in payment of taxes. While taxpayers write checks drawn on private banks to pay taxes, actually, when government receives these checks it debits the reserves of the private banks — reserves that are the central bank’s IOU. Effectively, private banks intermediate between taxpayers and government, making payment in currency and reserves on behalf of the taxpayers. Once the banks have made these payments, the taxpayer has fulfilled her obligation, so the tax liability is eliminated.

We conclude that government's "fiat" currency is accepted because it is the main thing (and usually the only thing) accepted by government in payment of taxes. It is true, of course, that government currency can be used for other purposes: currency can be used to make purchases, to settle debts, or to save in "piggy banks." However, these other uses of currency derive from government's willingness to accept its currency in tax payments. Ultimately, it is because anyone with tax obligations can use currency to eliminate these liabilities that government currency is in demand, and thus can be used in purchases or in payment of private obligations.

For this reason, neither reserves of precious metals (or foreign currencies) nor legal tender laws are necessary to ensure acceptance of the government's currency. We conclude that taxes drive money. The government first creates a money of account (the Dollar, the Pound, the Euro), and then imposes tax obligations in that national money of account. In all modern nations this is sufficient to ensure that many (indeed, most) debts, assets, and prices, will also be denominated in the national money of account. The government is then able to issue a currency that is also denominated in the same money of account, so long as it accepts its currency in tax payment. It "spends” this currency into existence, and destroys it by accepting it at government pay offices. 
This gets us part way to an explanation of why money IOUs are almost without exception denominated in some state's money of account. The sovereign power chooses the money of account when it imposes a tax liability in that unit. Keynes also recognized the state's role in choosing the money of account when he argued that the state

comes in first of all as the authority of law which enforces the payment of the thing which corresponds to the name or description in the contracts. But it comes in doubly when, in addition, it claims the right to determine and declare what thing corresponds to the name, and to vary its declaration from time to timewhen, that is to say, it claims the right to re-edit the dictionary. This right is claimed by all modern states and has been so claimed for some four thousand years at least (Keynes 1976 [1930], vol. 1, p. 4).

(This is why I ironically titled my book Understanding Modern Money in the sense that it applied only to the last "four thousand years at least" — whatever might have happened previous to that may not be "modern money." We will probably never know.)

Enforceability of monetary contracts in court is part of the reason nongovernment money IOUs are written in the state's money of account. In addition, money IOUs are often made convertible to the state's IOUs_-high powered money. This can make them more acceptable.

Here's the problem, however: merely agreeing to accept your own IOU in payment is a relatively easy promise to keep. But promising to convert your IOU to another entity's IOU (especially on demand and at a fixed exchange rate-which is necessary for par clearing in a money of account) is more difficult. It requires that one either maintain a reserve of the other entity's IOUs, or that it have easy access to those IOUs when required to do the conversion. Failure to meet the promise of conversion is a default. Hence, there is additional default risk that arises from a promise to convert, to be weighed against the enhancement to an IOU's general acceptability.

\section{REVISITING LIQUIDITY PREFERENCE}

This gives rise to the concept of liquidity: how quickly can an asset be converted with little loss of value? Generally, the most liquid asset is the state's own IOUs (the state promises to convert its IOUs to its own IOUs, and to accept those in all payments due to the state), so the conversion of other liabilities is often to HPM. Banks hold some HPM so that they can meet demands for conversion, but it is access to deposit insurance as well as to the central bank's discount window that makes the bank's promise to convert secure. Deposit insurance means the government, 
itself, will convert the bank liabilities to HPM at par; access to the central bank means that a bank can borrow HPM as necessary to cover conversions.

Here we can refer to the concept of a pyramid of liabilities-IOUs issued by other institutions and households are convertible to bank liabilities (Bell 2000; Foley 1989). These other entities then work out arrangements that make it more likely that they can meet demands for conversion, such as overdraft facilities. Everything is then pyramided on the state's IOUswe can think of that as a leveraging of HPM.

All promises are not equally valid, however-risk of default varies across the categories of IOUs. Above, we briefly addressed another fundamental principle of debts: one cannot pay one's debt using one's own IOUs. But the sovereign state is special. When the sovereign is presented with its own IOU, it promises to exchange that IOU for another of its IOUs, or it allows the presenter to "redeem" it in payment of taxes. The state makes its own paymentsincluding paying off its debts - using its own IOUs. To be sure, the state can retire its liabilities_-by running a budget surplus_-but it does not have to pay them down by using another's IOU. So the sovereign state really is special. So long as it does not promise to convert its IOUs on demand to any other IOUs (such as foreign currency) or to precious metal, it can never be forced into a situation in which it will default. All other entities must provide a second party or third party IOU to retire debt. For most purposes, it will be the liability of a bank that is used to make payments on one's debt if one is not the sovereign. Still, no bank can pay its own IOUs by issuing its own IOUs. That is why bank underwriting matters: each bank needs to ensure that the value of its assets does not fall below the value of its liabilities.

Default risk on a bank’s IOUs is small (and nonexistent in the case of government guaranteed deposits), hence bank liabilities are widely accepted. Banks specialize in underwriting (assessing credit-worthiness of) "borrowers"- those whose IOUs they hold. Not only do banks intermediate between government and its taxpayers but they also intermediate by accepting borrowers' IOUs and issuing their own IOUs. (While orthodoxy presents banking as intermediation between "savers" and "investors" this is incorrect—what is provided by a "saver" is the bank's IOU, created in the financing of the activities of the "investor." Investment creates saving, just as loans create deposits.) The IOUs they hold generally have higher default risk (except in the case of government debt), and are less liquid than the IOUs they issue. For this service, they earn profits, in large part determined by their ability to charge a higher interest rate on the IOUs they hold than the rate they must pay on their own. Again, the image of a debt 
pyramid is useful - those lower in the pyramid use the IOUs issued by entities higher in the pyramid to make payments and to retire debt.

This leads us to the interest rate, which, as Keynes said, is a reward for parting with liquidity. Since government-issued currency (cash) is the most liquid asset, it does not have to pay interest; bank demand deposits can be just as liquid (given government backing as discussed above) and for many purposes are even more convenient than cash, so they do not necessarily need to pay interest (in some cases, banks charge fees for checking accounts; in others, they do pay positive interest - this has to do with regulation and competition, issues we will not address). Other IOUs that are less liquid must pay interest to induce wealth-owners to hold them. In addition, interest compensates for default risk; this is in addition to the compensation for illiquidity of the asset. "Money," the most liquid asset, sets the standard (all other assets must earn a higher return) because it best satisfies the preference for liquidity. The desire for liquidity constrains effective demand and results in unemployment because the MEM acts as a barrier to activity in the industrial sphere (Keynes 1964 (1936); Davidson 1978).

We return to Goodhart's (2008) argument that conventional economics has no room for money because there is no default risk in rigorous models. For Keynes, conventional economics lacks a plausible theory of money holding precisely because there is no fundamental uncertainty in the models, which is necessary to explain why liquidity has value. The two arguments are related, and explain why financial institutions are important: they issue liquid IOUs with little (or no) default risk. This is the reason why their IOUs are frequently classified as "money," while the money IOUs of others are not. Hence, as Minsky claimed, "everyone can create money;” but he goes on: “the problem is to get it accepted” (Minsky 1986, p. 228). IOUs issued by heterogeneous agents are not equally acceptable.

Banks are special in another way: almost all the assets they hold are purchased by issuing IOUs. Typically, a bank has 5-8 percent equity against its assets, meaning that its liabilities are equal to 92-95 percent of the value of its assets. This is an extremely high leverage ratio (the bank’s asset to capital ratio is from 12.5 to 20). As Minsky (1986) put it, banks finance their positions in assets by issuing debt. Without guarantees of access to the central bank (to make their liabilities more liquid) and to government insurance (to reduce default risk on their liabilities), banks could not operate with such high leverage ratios.

Finally, IOUs are not just held or presented for payment (of one’s own liability). They are also to varying degrees transferable. For example, your neighbor might transfer your sugar 
IOU_-perhaps in payment of some sugar debt--to another neighbor, who could present it to you with a demand for sugar. Transferability of your IOU is limited to those who know you well and who trust that you are good for the sugar. Again, heterogeneity matters.

Since "money” is commonly associated with transferability of a debt amongst third parties, it is not surprising that government currency as well as bank liabilities are most often included in empirical definitions of money. The liabilities of nonfinancial corporations, or households, are not usually called money because they do not circulate readily among third parties. (Securitization of home mortgage loans - as well as various kinds of insurance plus certified credit ratings - made them transferable to some degree.) What the lay person identifies as money is usually even narrower, something that can be used in a market as a medium of exchange - to buy a commodity. And that, of course, must be a monetary IOU that is highly acceptable - a government IOU, a bank IOU, or an IOU closely backed by a bank (such as your credit card debt).

\section{BANKERS AS THE CIRCUIT’S “EPHOR”}

It is not surprising that circuitistes chose to begin analysis with banks-Schumpeter's “ephor of capitalism”- who, through the underwriting process, decide which economic activities get financed. Ironically, we moved beyond underwriting and beyond banks over the past couple of decades, and toward Minsky’s vision that "anyone can create money.” I have heard many PKs insist that banks still hold the key because only banks can create "real money," but this is not true. I can undertake economic activity if you will accept my IOU_let us say, to hire you to dig holes in my garden. So long as you will work for my IOUs, all is fine and dandy. But you want groceries. No problem—so long as the grocer is willing to take your IOU while accepting mine as collateral. The grocer, of course, must pay the wholesaler-but again that is no problem since your IOUs can be discounted. This is the concept behind financialization of the economy by shadow banks. Out in the real world, we’ve reached the "nth” degree-derivatives are about $\$ 600$ trillion, all supporting and supported by global GDP which is miniscule by comparison. It is time for the circuitistes to recognize reality.

This is why Minsky’s insights were so prescient: anyone can create money; the problem lies in getting them accepted. Rather than looking to banks to “create money” in Minsky’s vision the business of banking is "accepting”- taking an IOU and financing its position in that 
IOU by issuing its own IOU. This is the essence of financialization—or pyramiding—layers of debt that represent commitments of prospective future income flows. It is true that banks play a special role in the payments system - a special role owed in part to the government backstop (lender of last resort and deposit insurance) which ensures that bank IOUs are convertible to government IOUs. Yet accounts can clear without using the central bank's balance sheet; clearing at the central bank can become a "last resort"-maybe only net clearing, maybe not even that in normal circumstances. Yet, when the crisis hits, the shadow financial institutions find they cannot refinance positions - in other words, they cannot reissue liabilities to cover their positions in assets. This is precisely what happened in 2007, when shadow banks—which had relied on very short term commercial paper to finance positions in mortgage backed securities and other assets—could not refinance. Banking deposits had become a very minor part of the "financing" of financial institution positions in "loans." Unfortunately for the banks, the alternative sources they had been using were not guaranteed and hence, when the crisis hit, they faced a run.

The crisis exposed the weakness of taking the circuit model too seriously. Certainly, economic activity needs finance, but this is not necessarily through loans but rather through "acceptation"-accepting liabilities. And financial institutions need to finance their positions in the assets they hold by issuing liabilities, but these are not necessarily deposits. Nor are banks the only type of financial institutions capable of financing economic activity. Much of the financing activity takes place off the balance sheets of banks. To be sure, moving activity to the shadow banks depended on a view of the economy — the belief in Bernanke's "great moderation" helped to promote the view that risk had fallen. Preference for safety and liquidity had become outdated. Exactly as Minsky had argued, the "run of good times" in the postwar period had changed expectations in a way that diminished the value of liquidity and margins of safety. This made the great crash a possible outcome. "It" could happen again. "It" did happen again! "It" is still happening!

\section{CONCLUSION}

The circuit approach has proved to be an extremely useful tool for analyzing what Keynes called the monetary theory of production. We need to begin analysis of production with finance. Money created moves through the circuit from payment of wages back to producers and on to 
banks to destroy the money. In the simple circuit, default is ignored; extensions do allow for saving, which prevents some loans from being repaid, and hence some of the money is not destroyed. Bonds can be sold to recapture some of the saving-allowing short term loans to be repaid, but that only substitutes longer term debt. This opens an avenue for liquidity preference, which determines willingness to give up deposits for bonds. Allowing for default provides another path for liquidity preference to enter; if default is uncertain (and not merely probabilistic), then a preference for liquid assets can exist.

We also must allow for a range of financial institutions, all of which “create money” but only some of which have access to the central bank and the government insure. This provides another opportunity for liquidity preference to matter-these money IOUs are not equally acceptable. The state matters doubly: it creates the unit of account in which all money IOUs are denominated, and it backstops some portion of those money IOUs to make them more liquid. The state enforces its choice by accepting only certain IOUs and only those denominated in its own currency of account. It thus uses the monetary system to move a portion of resources to the public purpose. A monetary circuit without the state is even worse than Hamlet without the Prince.

Keynes introduced liquidity preference in the investment decision, with liquidity preference interpreted as a theory of value. Here is where the bulls and bears matter-when the bears dominate, the industrial circulation suffers. Unemployment exists because "men” want the moon-raising the MEM to such a level that production of commodities cannot be undertaken.

In this chapter I have mostly echoed the themes in the paper provided by Alain Parguez for this conference. He, too, begins with state money: "money could not exist without a State," with the state's money serving as the “anchor” for credit (Parquez, Rochon, and Seccareccia 2012, p. 2). According to Parguez, there are two "Newtonian laws” applying to monetary circulation: "the monetary circuit is the ultimate existential condition of the capitalist system" and "it cannot exist without the state" (Ibid., p.2). At the center of the system we have the “banking system,” which includes private banks and the central bank (Ibid., p. 5). Their liabilities are denominated in state currency units. Rather than arguing that money is created "ex nihilo,” it is spent into existence - this is what gives it pure extrinsic value. It is never dropped by Friedmanian helicopters, but rather its creation motivates resources-workers, "natural” resources, and produced commodities are put to use, with money motivating the "production of commodities by means of commodities” (Sraffa 1960). Money is required at both the beginning 
and the end of that production - it mobilizes the resources, but only if "more money" is expected at the end. Privately created money is destroyed when loans are repaid; government's money is destroyed when taxes are paid. While private money creation and commodity production is constrained by expectations of profits, government money creation is not similarly constrained. For that reason, the state can and must play the balancing role, keeping the industrial circulation operating at capacity.

This however, requires floating exchange rates; "the State as master of its currency, cannot be obliged to redeem its currency at a fixed price [because] the State would be sharply constrained in its ability to spend. Thereby the monetary circuit law imposes a perfectly floating exchange rate system” (Parquez, Rochon, and Seccareccia 2012, p. 8). And that is why the EMU is a Frankenstein's monster: each individual state has essentially adopted a currency board arrangement with a fixed exchange rate that constrains fiscal policy. This is why Euro nations could not deal with the financial crisis—a crisis that was always inevitable. Their only option in the face of recession is austerity—adding fiscal headwinds to the private headwinds. What Parguez calls "bad deficits" explode and threaten national insolvency.

Still there is hope. The crisis provides an opportunity to downsize finance and to take the "predator” out of Jamie Galbraith’s Predator State (Ibid., p. 17). Rather than serving in the interests of the most rapacious globalized corporations, the state needs to finance public investment, education, and research. While difficult, this is possible for all sovereign nations that have their own floating currency. But for the EMU, this is currently impossible. European states can only be saved by restoring their sovereignty (Ibid., p. 20). This could be done through the creation of a "more perfect union;" however, that is not likely—mostly for political, social, and cultural reasons. That leaves only dissolution of the union. Greece, Ireland, and Italy are currently under tremendous pressure to quit—with France and Germany apparently believing they have the upper hand. Yet if any of these countries are forced to leave by the onerous terms imposed by the center, the dominoes will fall as markets will run against all the other periphery nations. That will leave the center nations without their colonial outposts, so they will turn on each other. What began as a great political experiment to ensure the end of European Great Wars may actually end in the third violent go-round.

As Keynes put it: "The classical theorists resemble Euclidean geometers in a nonEuclidean world who, discovering that in experience straight lines apparently parallel often meet, rebuke the lines for not keeping straight—as the only remedy for the unfortunate 
collisions which are occurring. Yet, in truth, there is no remedy except to throw over the axiom of parallels and to work out a non-Euclidean geometry” (Keynes 1973, p. 366). To make progress in our understanding of the monetary economy, we have got to put bulls, bears, and states into the circuit. That is our non-Euclidean geometry. 


\section{REFERENCES}

Bell, Stephanie. 2000. “Do taxes and bonds finance government spending?” Journal of Economic Issues 34: 603-620.

Davidson, P. 1978. Money and the Real World. London, UK: Macmillan.

Foley, D. 1989. "Money in Economic Activity” In Eatwell, John, Murray Milgate, and Peter Newman, eds., The New Palgrave: Money. New York, NY and London, UK: W.W. Norton.

Goodhart, Charles A.E. 1998. "Two concepts of money: implications for the analysis of optimal currency areas.” European Journal of Political Economy 14:407-432.

—. 2008. "Money and Default," In Forstater, Mathew and L. Randall Wray, eds., Keynes for the Twenty-First Century: The Continuing Relevance of The General Theory. Palgrave/Macmillan: 213-223.

Graziani, A. 1990. "The theory of the monetary circuit.” Economies et Sociétés 7(6).

Innes, A. M. 1913. "What is money?” Banking Law Journal 30(5): 377-408. Reprinted in L. R. Wray (ed.). 2004. Credit and State Theories of Money. Cheltenham, UK and Northampton, MA, USA: Edward Elgar: 14-49.

Kalecki, M. 1971. "The determinants of profits.” In M. Kalecki (ed.) Selected Essays on the Dynamics of the Capitalist Economy. Cambridge, UK: Cambridge University Press: 7892.

Keynes, John Maynard. 1964. The General Theory of Employment, Interest and Money. New York, NY and London, UK: Harcourt Brace Jovanovich.

—. 1973. Vol. XIV: The General Theory and After. Part II, Defense and Development. London, UK: Macmillan and Cambridge University Press for the Royal Economic Society. 1976. A Treatise on Money. Volumes I and II. New York, NY: Harcourt, Brace \& Co.

Knapp, G. F. 1924. The State Theory of Money. Clifton, NY: Augustus M. Kelley.

Kregel, J.A. 1986. "Shylock and Hamlet: Are there Bulls and Bears in the Circuit?" Economie et Sociétés série MP 3: 11-22.

_ 1976. "Economic methodology in the face of uncertainty: The modeling methods of Keynes and the Post-Keynesians.” Economic Journal 86 (342): 209-225.

Minsky, Hyman P. 1975. John Maynard Keynes. New Haven, CT: Yale University Press. 
—. 1986. Stabilizing an Unstable Economy. New Haven, CT: Yale University Press.

Parquez, Alain, Louis-Philippe Rochon, and Mario Seccareccia, eds. 2012. Contemporary Capitalism: Finance, Transformation, and Prospects-Essays in Honour of Alain Parquez, Louis-Phiippe Rochon and Mario Seccareccia. Cheltenham, UK: Edward Elgar.

Sraffa, Piero. 1960. Production of Commodities by Means of Commodities: Prelude to a Critique of Economic Theory. Cambridge, UK: Cambridge University Press.

Wray, L. Randall. 1990. Money and Credit in Capitalist Economies: The EndogenousMoney Approach. Aldershot, UK and Brookfield, VT, USA: Edward Elgar. 1998. Understanding Modern Money: The Key to Full Employment and Price Stability. Northampton, MA: Edward Elgar.

- 2004. Credit and State Theories of Money. Cheltenham, UK and Northampton, MA, USA: Edward Elgar.

_ 2009. "The rise and fall of money manager capitalism: a Minskian approach." Cambridge Journal of Economics 33 (4): 807-828 